\title{
Evaluation of the metabolic response to open and minimally invasive resection of the oesophagus due to oesophageal cancer
}

\author{
Jarosław Pieróg ${ }^{1}$, Michał Bielewicz ${ }^{1}$, Janusz Wójcik ${ }^{1}$, Bartosz Kubisa ${ }^{1}$, Krzysztof Kaseja ${ }^{1}$, \\ Krzysztof Safranow ${ }^{2}$, Barbara Dołęgowska ${ }^{3}$, Piotr Waloszczyk ${ }^{1}$, Tomasz Grodzki ${ }^{1}$
}

${ }^{1}$ Thoracic Surgery and Lung Transplantation Department, Pomeranian Medical University, Szczecin, Poland

2Department of Biochemistry and Medical Chemistry, Pomeranian Medical University, Szczecin, Poland

${ }^{3}$ Department of Microbiology, Immunology and Laboratory Medicine, Pomeranian Medical University, Szczecin, Poland

Kardiochirurgia i Torakochirurgia Polska 2018; 15 (3): 151-156

\begin{abstract}
Aim: The aim of this study was to compare the metabolic response in the early postoperative period after radical resection of stage I and II oesophageal cancer applying a minimally invasive procedure and an open procedure involving classical laparotomy and thoracotomy.

Material and methods: Serum concentrations of interleukin 6 (IL-6), procalcitonin (PCT), C-reactive protein (CRP), tumour necrosis factor- $\alpha$ (TNF- $\alpha$ ), and total serum protein (TP) and leukocyte count (WBC) in blood collected on the day of surgery prior to the procedure (day 0) and on days 1, 2 and 7 after the surgery were measured in two groups of patients undergoing oesophageal resection due to cancer: applying a minimally invasive procedure involving laparoscopy and videothoracoscopy (group A) and applying a classical procedure involving full opening of the chest and abdominal cavity (group B). The study involved a total of 24 patients divided into two groups of 12 patients each.

Results: Tumour necrosis factor- $\alpha$ concentration was lower in group $\mathrm{A}$ compared to group $\mathrm{B}$ on day $\mathrm{O}, \mathrm{PCT}$ concentration was lower in group $A$ compared to group $B$ on day 2 after surgery, and on the remaining days TNF- $\alpha$ and PCT concentrations were not statistically different between groups. Conclusions: Lower concentration of PCT on post-surgery day 2 in the group of patients undergoing minimally invasive oesophageal resection seems to be associated with a smaller perioperative injury. Lower TNF- $\alpha$ concentration in serum collected on day 0 in the group of patients undergoing minimally invasive resection is associated with a lower stage of oesophageal cancer in this group.
\end{abstract}

Key words: minimally invasive resection of oesophagus, oesophageal cancer, metabolic response.

\section{Streszczenie}

Cel pracy: Porównanie odpowiedzi metabolicznej organizmu we wczesnym okresie pooperacyjnym po radykalnej resekcji raka przełyku w stopniu zaawansowania I i II sposobem matoinwazyjnym i sposobem związanym z wykonaniem klasycznych dostępów do jamy brzusznej (laparotomii) i klatki piersiowej (torakotomii).

Materiał i metody: Badano stężenia interleukiny 6 (IL-6), prokalcytoniny $(\mathrm{PCT})$, białka C-reaktywnego (CRP), czynnika martwicy nowotworów $\alpha$ (TNF- $\alpha$ ), białka całkowitego (TP) w surowicy oraz liczbę leukocytów (WBC) we krwi pobranej w dniu operacji przed zabiegiem (doba 0) oraz w 1., 2. i 7. dobie pooperacyjnej $w$ dwóch grupach chorych poddanych resekcji przełyku z powodu raka: sposobem małoinwazyjnym z zastosowaniem laparoskopii oraz wideotorakoskopii (grupa A) i sposobem klasycznym - z wykonaniem laparotomii i torakotomii (grupa B). W badaniu wzięło udział łącznie 24 pacjentów podzielonych na dwie równe liczebnie grupy składające się każda z 12 pacjentów.

Wyniki: Stężenie TNF- $\alpha$ było mniejsze $w$ grupie A niż w grupie $B$ w dobie 0 , stężenie $P C T$ - mniejsze $w$ grupie $A$ niż $w$ grupie B $w 2$ 2. dobie pooperacyjnej, w pozostałych dobach stężenia TNF- $\alpha$ i PCT w obu grupach nie różnity się statystycznie.

Wnioski: Wydaje się, że mniejsze stężenie PCT w 2. dobie pooperacyjnej u pacjentów poddanych resekcji przetyku sposobem małoinwazyjnym wiąże się z mniejszym urazem okołooperacyjnym. Mniejsze stężenie TNF- $\alpha$ u pacjentów poddanych resekcji sposobem małoinwazyjnym w surowicy pobrane w dobie 0 jest związane z mniejszym stopniem zaawansowania raka przełyku $\mathrm{w}$ tej grupie.

Słowa kluczowe: resekcja małoinwazyjna przełyku, rak przełyku, odpowiedź metaboliczna organizmu.

Address for correspondence: Jarosław Pieróg MD, Thoracic Surgery and Lung Transplantation Department, Pomeranian Medical University, 11 Sokołowskiego St, 70-789 Szczecin, Poland, phone: +48 501797 564, fax: +48 9146208 36, e-mail jarpi@op.pl Received: 8.04.2018, accepted: 12.06.2018. 


\section{Introduction}

A surgical resection for oesophageal cancer is estimated to be possible in 30-50\% of diagnosed cases; however, long-term survival of patients after radical surgical treatment is still unsatisfactory, and the 5-year survival rate is between $10 \%$ and $25 \%$ [1]. As oesophageal cancer does not present with early symptoms; it is diagnosed at advanced stages in the majority of developed countries. Cigarette smoking and frequent consumption of high-proof alcohol is the main aetiological factor for oesophageal squamous epithelial cancer [2]. Incidence, duration and exacerbation of symptoms of gastroesophageal reflux contribute to an increased risk of oesophageal adenocarcinoma [3]. Surgical resection still remains a method of choice with regard to radical treatment of oesophageal cancer despite undoubted advances in chemotherapy and radiation therapy. As oesophageal cancer has a malignant and unspecific course, in the majority of cases it is diagnosed at more advanced stages, and therefore the rate of resection cases is not satisfactory, and it is between $54 \%$ and $69 \%$ according to the literature [4]. A detailed analysis of perioperative risk, advances in surgery, anaesthesiology and intensive care contributed to a reduced rate of complications and deaths in the postoperative period [5]. A routine surgical method to treat oesophageal cancer includes complete or almost complete resection of the pathological oesophagus with adjacent lymph nodes with simultaneous restoration of the gastrointestinal tract integrity by moving the stomach, or rarely the intestine, after appropriate preparation of the chest or neck in order to perform an anastomosis between a prosthesis made from the stomach or intestines and the oesophageal stump. Depending on the tumour location and extent of lymphadenectomy the surgery may be performed traditionally with laparotomy, thoracotomy or with a minimally invasive approach such as laparoscopy and videothoracoscopy; an additional cervical approach (cervicotomy) is implemented similarly in both variants of surgical treatment, if necessary. The extent of lymphadenectomy has not been unequivocally determined [6]. According to various literature sources the mortality in the postoperative period after oesophagectomy varies between $10 \%$ and $15 \%$, but in large specialised centres where many such procedures are performed this rate is approximately 5\% [7]. Currently, a minimally invasive approach to treat oesophageal cancer (minimally invasive oesophagectomy - MIE) is more and more accepted. Neoadjuvant chemotherapy and radiation therapy are not contraindications for minimally invasive treatment [8]. It has been shown that when MIE is performed correctly, the prognosis with regard to the 5-year survival rate is not affected compared to treatment with classic methods [9]. Data presented in available literature favour MIE as an approach of choice when there are no contraindications for such treatment. In a series of 222 patients subject to MIE Luketich reported complications in the perioperative period at the level of $1.4 \%$ and a shorter time of hospitalisation. When analysing available literature there are few data comparing MIE to open oe- sophagectomy. Nguyen performed a retrospective comparison of patients subject to MIE, open surgery and transhiatal oesophagectomy, and reported shorter hospitalisation, lower blood loss and associated lower amount of blood products transfused in patients subject to MIE [10].

\section{Aim}

The aim of this study was to compare the metabolic response in the early postoperative period after radical resection of stage I and II oesophageal cancer applying a minimally invasive procedure and an open procedure involving classical laparotomy and thoracotomy.

\section{Material and methods}

All patients included in the study received radical surgery due to oesophageal cancer. Study material $(2 \mathrm{ml}$ of venous blood) was collected from all patients before the surgery - "sample 0", then at 7.00 on day 1 after the surgery - "sample 1", at 7.00 on day 2 after the surgery - "sample 2 ", and at 7.00 on day 7 after the surgery - "sample 7". The following parameters were assayed: blood leukocyte count, concentrations of procalcitonin, C-reactive protein (CRP), interleukin 6 and tumour necrosis factor- $\alpha$ (TNF- $\alpha$ ). The interleukin-6 (IL-6) and TNF- $\alpha$ levels in serum were assayed with ELISA using a multi-detection microplate reader, EnVision by Perkin Elmer (USA). In the period between the beginning of 2011 and the end of 2015 oesophagectomy was performed in 60 patients in total. A minimally invasive procedure was used in 16 patients, that is $26.6 \%$. Patients who were operated on because of indications other than oesophageal cancer were excluded from the study. Considering the sample size of patients treated with a minimally invasive approach for oesophageal cancer $(n=12)$ a corresponding subgroup $(n=12)$ of patients receiving traditional surgery was selected with similar age, sex and disease stage.

The study included 24 patients diagnosed with oesophageal cancer, divided into two groups of the same size, each including 12 patients who were subject to oesophagectomy with a minimally invasive approach (group A) and with a classic approach with chest and abdominal cavity opening, and with cervicotomy in a few cases. Group A included 3 women and 9 men, and the mean age was 59.5 years, whereas group B included 3 women and 9 men, and the mean age was 62.4 years - there was no statistically significant difference with regard to age between the groups. During the surgery all patients were intubated with a double-lumen tube to provide independent lung ventilation. Preoperative chemotherapy including 2 cycles of cisplatin and 5-fluorouracil (5-FU) and the total radiation dose of 45 Gy at 2 Gy per fraction was applied in 1 case in group $A$ and in 3 cases in group B. Patients who received a minimally invasive approach had initially laparoscopy with a Veress needle performed in order to create pneumoperitoneum, and with 5 ports to introduce a camera and manipulators into the peritoneal cavity. The gastrocolic ligament was dissected with a thermostapler, preserving the right gastrocolic artery supplying the gastric graft that was 
to replace a resected oesophageal fragment. Then, a thermostapler was used to provide for short gastric vessels and gastric vessels on the left. Pyloromyotomy or pyloroplasty was performed, followed by the Kocher manoeuvre to mobilise the duodenum. Lymph nodes from the area of the visceral trunk and the lesser curvature of the stomach were removed. A nutritional access - microjejunostomy - was placed. Then, the patient was reversed to the left flank, and 3 videothoracoports were placed mainly in the $4^{\text {th }}$ intercostal space in the anterior axillary line, in the $5^{\text {th }}$ intercostal space below the inferior angle of the scapula, and in the $8^{\text {th }}$ intercostal space approximately $2 \mathrm{~cm}$ posteriorly from the posterior axillary line. When the camera and manipulators were introduced, at the beginning the pulmonary ligament was raised, then the azygous vein was cut with a stapler, the mediastinal pleura was opened above the oesophagus with a thermostapler, and the pathological oesophagus was separated from the surrounding tissues. Then, the oesophagus with a tumour was resected, and with staplers an anastomosis was created between the oesophageal stump and the gastric graft at the place depending on the tumour location: inside the right pleural cavity (Ivor Lewis oesophagectomy) or with a cervical anastomosis (McKeown oesophagectomy). Mediastinal lymphadenectomy with resection of lymph nodes belonging to groups $4 R, 7$ and 8 was performed, and in cases with a cervical anastomosis, cervical lymphadenectomy was additionally performed. In patients treated with open surgery with median laparotomy and thoracotomy stomach dissection, lymphadenectomy and anastomoses were performed similarly as in minimally invasive oesophagectomy. In group A 4 patients had IvorLewis oesophagectomy performed, and in 8 cases threefield oesophagectomy with a cervical anastomosis was performed. In group B in 8 cases Ivor Lewis oesophagectomy with an anastomosis in the right pleural cavity was performed, and in 4 cases three-field oesophagectomy with a cervical anastomosis. In both groups squamous epithelial cancer was predominant - in group A it was diagnosed in

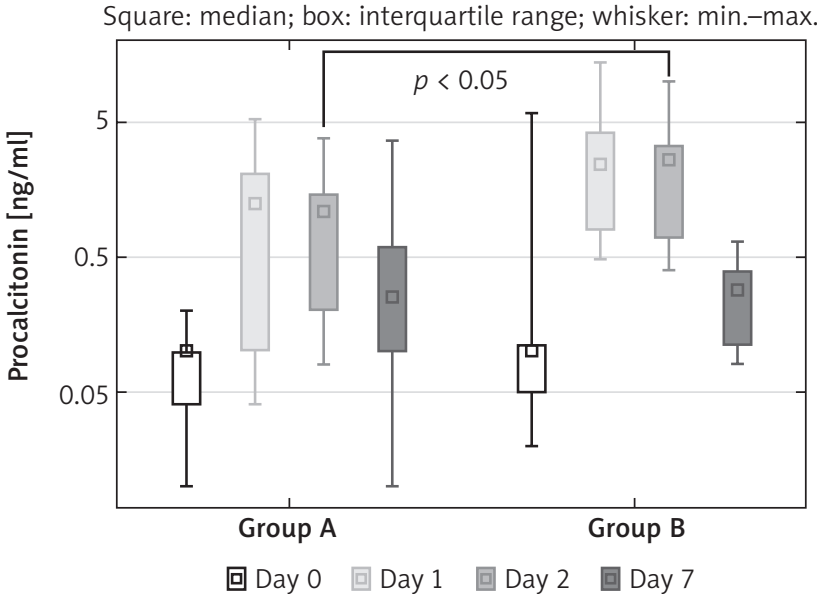

Fig. 1. Serum concentrations of procalcitonin in blood collected on days $0,1,2$, and 7 after the surgery in groups A and B. Values are presented on a logarithmic scale
10 cases compared to 7 cases in group B, whereas adenocarcinoma was present in group $A$ in 2 cases, and in 4 cases in group B. In 1 case poorly differentiated carcinoma was observed. Histopathologic findings of specimens confirmed a complete response in 2 cases $(A=1$ vs. $B=1), T_{\text {is }}(A=2$ vs. $B=1), T_{1}(A=5$ vs. $B=1), T_{2}(A=4$ vs. $B=6), T_{3}(A=1$ vs. $B=4)$. The $T$ parameter was significantly lower in group A vs. B ( $p<0.05$, Mann-Whitney test). Cancer metastases to the lymph nodes were observed in 5 cases in total $(A=2$ vs. $B=3)$. Staging of neoplastic disease in patients included in the study was determined based on the $7^{\text {th }}$ Edition of TNM classification for oesophageal cancer published by the Union for International Cancer Control (UICC) and the American Joint Committee on Cancer (AJCC) in 2010 [11].

\section{Statistical analysis}

The non-parametric Mann-Whitney test was used to compare quantitative and rank variables between groups. $P<0.05$ was considered statistically significant.

\section{Results}

The levels of procalcitonin on day 2 after the surgery were statistically significantly lower in group A compared to levels in group B $(p<0.05)$ (Fig. 1). The TNF- $\alpha$ levels on day 0 were statistically significantly lower in group A compared to group B $(p<0.05)$ (Fig. 2). No other statistically significant differences between the groups were found.

\section{Discussion}

Despite constant advances in diagnostic procedures, surgery and anaesthesiology, the rate of complications in the early postoperative period is still very high. The analysis of metabolic disorders after oesophagectomy due to cancer might contribute to better understanding of these phenomena that might be a reason for at least some complications in the early postoperative period. A surgical procedure is associated with a simultaneous large intervention in the

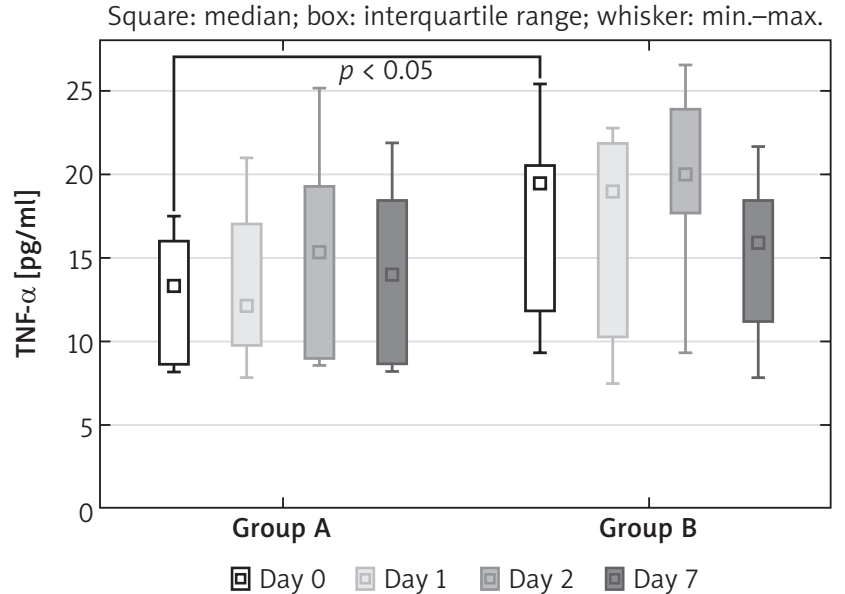

Fig. 2. Serum concentrations of TNF- $\alpha$ in blood collected on days $0,1,2$, and 7 after the surgery in groups $A$ and $B$ 
abdominal cavity, right pleural cavity and mediastinum; therefore undoubtedly it is a great stressogenic factor for the body resulting in numerous changes in its functioning. Minimally invasive procedures (VATS) have been shown to be associated with lower intensity of the systemic inflammatory response compared to procedures with chest opening. Oesophageal cancer affecting the upper gastrointestinal tract rapidly leads to nutritional deficiencies in the body, which affects the functioning of various systems and individual organs. The effects of a neoplastic disease on the body's metabolic functions are complex and not fully known. Changes in homeostasis are a result of both local and systemic effects of cancer, and lead to changes in the demand, supply and correct use of energetic and structural substrates. An inflammatory reaction induced by mediators and cytokines the presence of which is associated with an observed neoplastic process undoubtedly has a role to play in this phenomenon [12].

From a clinical point of view, oesophageal cancer and associated implications including malnutrition and body weight loss are undoubtedly poor prognostic factors. Oesophagectomy is associated with formation of a large wound, and it causes damage to tissue structures and functions of the surrounding organs in the abdominal cavity, pleural cavity, mediastinum and neck, resulting in a systemic response aimed at restoring the plasma levels to preoperative levels as fast as possible. As a result of local and systemic adaptation mechanisms, the body aims to restore the internal metabolic balance as soon as possible. With regard to the local reaction, blood vessel dilation and increased vascular wall permeability both play a significant role. A series of systemic mechanisms aims to regenerate injuries at the tissue level and to restore appropriate functioning of internal organs. Such mediators as serotonin and histamine are released from stimulated inflammatory cells, and tissue and plasma proteolytic systems are activated. It is known that inflammation may in some cases be beneficial to the body. It helps eliminate necrotic products, stop bleeding due to a trauma or remove exudate with endoand exotoxins. This phenomenon was described in 1941 by Abernethy and Avery as an acute phase reaction. They analysed parameters of the plasma in a patient with a fever, and found the presence of CRP. Acute phase proteins (APPS) are mainly synthesised in the liver. Acute phase proteins are also produced by lymphocytes, monocytes, alveolar macrophages and by the cells in the blood vessel walls. Acute phase proteins are involved in limitation of the extent of the inflammatory process and elimination of its sequelae. Their main role is to restore a systemic balance as a result of induction of the complement system and unspecific reactions associated with opsonisation and agglutination. Apart from their effects on the immune system they regulate release of some hormones, such as ACTH. Acute phase proteins can be divided into positive proteins, the levels of which increase by at least $25 \%$ (i.e. $\alpha_{1}$-antichymotrypsin, $\alpha_{1}$-antitrypsin, procalcitonin, ceruloplasmin) and negative proteins, the levels of which decrease by approximately
$30 \%$ (prealbumins, albumins, transferrin) [13]. The levels of negative acute phase proteins are reduced as a result of an inflammatory reaction associated with their increased catabolism and reduced synthesis in the liver. In this study only the procalcitonin levels were statistically significantly lower in group A on day 2 after the surgery, and it may be explained by a smaller perioperative trauma compared to group B. However, no similar correlation was observed regarding the levels of CRP, proinflammatory cytokines TNF- $\alpha$ and IL-6, and the leukocyte count.

The IL- 6 levels increase in serious burns, sepsis and connective tissue diseases. It has been demonstrated that the levels of this cytokine reflect the degree and extent of burns and indicate a period of wound healing [14]. Pyrogenic effects of IL- 6 have been confirmed, and along with TNF- $\alpha$ this cytokine may increase the body temperature via stimulation of prostaglandin synthesis and induction of synthesis of corticotropin and adrenocorticotropic hormone. How the IL- 6 levels change in the early postoperative period is not fully determined. Okamura et al. observed increased IL-6 levels after minimally invasive oesophagectomy due to cancer on day 1 after the surgery, with gradually reduced levels on subsequent days [15]. On the other hand, Fang et al. compared IL-6 levels after minimally invasive procedures and open procedures due to oesophageal cancer, and did not observe any statistically significant differences in the levels in the early postoperative period. In the literature a correlation has been reported between elevated IL-6 levels and advanced neoplastic disease, especially with accompanying metastases and cachexia. When analysing the IL-6 levels in patients with colon cancer, Kemik et al. observed higher IL-6 levels in patients with liver metastases compared to those without such metastases [16]. Contrary to such APPs as IL- 6 or TNF- $\alpha$, procalcitonin is associated with short time of response to a damaging factor, especially compared to CRP, which is routinely assayed. It is of special importance when assessing the clinical status in critical cases. Procalcitonin has many properties and therefore it can be potentially used as a biomarker in clinical practice. It has wide bioavailability, a short response time and a long half-life period. Elevated procalcitonin levels have been shown to be associated with severe perioperative trauma, some autoimmune diseases and a cardiogenic shock, apart from bacterial infections. However, in the case of cholecystitis, appendicitis, tonsillitis or limited inflammatory processes, there is no significant increase in the procalcitonin levels, contrary to proinflammatory cytokines [17]. In the literature there are opposing opinions regarding the clinical usefulness of procalcitonin, and therefore further studies are necessary. A persistent increase in the procalcitonin levels or no reduction is associated with an increased risk of organ dysfunction and mortality. A correlation has been demonstrated between the procalcitonin levels and an increased risk of death as a result of cancer, especially for colon cancer and cardiovascular disease in men. It is associated with an inflammatory process that plays the main role in the pathogenesis of both these dis- 
eases. It is thought that the procalcitonin levels may reflect subclinical inflammation better than high-sensitivity CRP (hsCRP), which is a well-known inflammatory marker. When analysing the properties of procalcitonin, especially its halflife period of $24 \mathrm{~h}$, with everyday measurements of levels of this acute phase protein it is possible to predict the degree of body injuries and to monitor the efficacy of treatment. When elevated levels of procalcitonin are maintained or its levels increase, it indicates a permanent inflammatory process, whereas a constant and significant reduction is a good prognostic factor that indicates improvement of the patient's health status.

In healthy people the CRP levels are minimal. It is thought that its levels are usually below $5.0 \mathrm{mg} / \mathrm{l}$, and the half-life period is $19 \mathrm{~h}$. As a result of a response to a damaging stimulus the levels may rise significantly, and reach peak levels within $48 \mathrm{~h}$. Because of a short biological half-life period the CRP levels rapidly return to normal levels when a damaging factor has been eliminated. It is known that the most important role of CRP is to fight bacterial infections and to eliminate dead cells and their fragments from the body. Tests regarding the CRP levels were also introduced in patients with malignant cancer. It has been demonstrated that in malignant gastrointestinal tumours such as colon cancer or pancreatic cancer the changes in the CRP levels depend on the tumour dimensions and cancer grade [18]. The CRP levels in patients with oesophageal cancer such as squamous epithelial cell cancer or adenocarcinoma are an independent prognostic factor. Crumley et al. demonstrated that CRP levels below $10 \mathrm{mg} / \mathrm{l}$ before a surgery in patients with oesophageal cancer were associated with longer survival - a median of 79 months vs. 19 months in patients with the CRP levels above $10 \mathrm{mg} / \mathrm{l}$ [19].

It seems debatable whether elevated CRP levels indicate the activity of a neoplastic process, or whether it is a type of an active body response to the presence of a neoplastic process. This first possibility is supported by the elevated IL-6 levels in cancer patients, as well as a strong correlation between IL- 6 levels and CRP, which confirms a key role of IL- 6 in the regulation of CRP production. Using an example of kidney cancer it has been demonstrated that the IL- 6 levels in the venous blood near a kidney tumour were 10 times higher compared to the value in the peripheral blood, and it confirms that renal cancer cells produce IL-6 [20].

The elevated CRP levels in patients with symptoms of cachexia and a correlation between the CRP levels and other immune markers may suggest that the body's response during an acute phase reaction is important. The CRP levels also increase in the early postoperative period because of trauma due to tissue damage. Huang et al. demonstrated reduced CRP levels on days 1 and 2 after the surgery in patients with oesophageal cancer treated with a minimally invasive approach compared to a group of patients treated with open surgery [21]. It is recommended to determine CRP and other APPs when calculating parameters indicating malnutrition and inflammatory markers in the period before and after surgery in patients with malignancies.
The healing process can be generally divided into the following consecutive stages: haemostasis, inflammation, migration and proliferation of cells, protein synthesis, wound contraction followed by scar formation and further remodelling. All significant traumas cause vascular damage and impair vascular integrity; namely they initiate a molecular and cellular response leading to haemostasis. Healing starts only after haemostasis mechanisms have been implemented, and they include a multifactorial and multistage process. In the inflammation stage there are signs typical of inflammation such as reddening, swelling, pain and lack of normal functioning of an organ or tissue affected by this process. One of the main signs of inflammation is migration of leukocytes into the area affected by inflammation. These cells have phagocytic capability and clean a wound. These cells have phagocytic capability and clean a wound. Although it is assumed that inflammation is the second stage of wound healing, its symptoms, such as erythema and warmth, develop soon after a damaging factor has been observed, as a result of blood dilation. Migration of white blood cells is stimulated by factors belonging to products of disintegration of elastin and collagen, complement system components, and TNF- $\alpha$ and IL-1 cytokines [22]. Phagocytising cells also produce many cytokines, such as IL-1 and IL-6, that affect the inflammatory process and associated healing process via activation of T-cells, and these cells are a source of proinflammatory factors such as TNF- $\alpha$.

The wound healing process depends to a large extent on cytokines that control the activation of a gene responsible for migration and proliferation of cells. Thrombocytes and macrophages are key for cytokine synthesis; however, other cells can also produce them. Cytokine release is partially mediated by other cytokines as well. Tissue hypoxia is also important, as it stimulates the release of endothelial growth factor (VEGF), TGF- $\beta$, TNF- $\alpha$ and IL-8 [23].

Additionally, cytokines are released by cells of organs affected by a neoplastic process, and are directly produced by cancer cells. The TNF- $\alpha$ is produced by many cells such as activated monocytes, macrophages, B- and T-cells and fibroblasts. The TNF- $\alpha$ is synthesised by cancer cells, and may stimulate growth of other cancers. It is also involved in each aspect of the carcinogenetic process, namely transformation, proliferation, angiogenesis and metastasis formation. It was confirmed that this cytokine was involved in neoplastic transformation, as elevated serum levels of TNF- $\alpha$ were observed in people with various types of cancer, and increased expression of this cytokine has been reported in precancerous conditions [24]. Aydin et al. analysed the TNF- $\alpha$ and IL- 6 levels in patients with oesophageal cancer who had not been operated on. Patients with oesophageal cancer showed significantly elevated levels of TNF- $\alpha(3 \times)$ and IL-6 (10x), namely proinflammatory cytokines. The levels of TNF- $\alpha$ and IL- 6 strongly correlated with the body weight loss in the course of oesophageal cancer [25]. The authors suggested that measurements of the IL-6 and TNF- $\alpha$ levels as markers to diagnose oesophageal cancer were extremely useful. 


\section{Conclusions}

The present study did not show any significant differences in the levels of procalcitonin (apart from day 2 after the surgery), IL-6, TNF- $\alpha$, leukocyte count and protein levels in the early postoperative period between patients who had oesophagectomy with a minimally invasive approach and a method with traditional laparotomy and thoracotomy. Higher preoperative TNF- $\alpha$ serum levels in patients receiving traditional treatment compared to those receiving minimally invasive surgery correlate with a higher initial grade of cancer in the first group. After the surgery, the TNF- $\alpha$ levels did not differ significantly between the studied groups. It seems that a smaller surgical trauma associated with a minimally invasive approach is not significantly associated with reduced levels of APPs, total plasma protein, pro-inflammatory cytokines or WBC in the early postoperative period. It may be explained by the fact that dissection and preparation of a gastric graft and its movement into the site of a resected oesophagus as well as methods used to perform an anastomosis between the stomach and the oesophageal stump in the chest or neck are associated with a similar perioperative trauma, and the subsequent healing process is not significantly different between study groups. However, it has to be emphasised that the population of patients receiving radical surgical treatment due to oesophageal cancer in Poland is not large, and therefore this report includes study groups with a limited size. Despite this, the conclusions from results obtained correlated in the majority with conclusions available in the current world literature.

\section{Disclosure}

The authors report no conflict of interest.

\section{References}

1. Bosetti C, Levi F, Ferlay J, Garavello W, Luccini F, Bertuccio P, Negri E, La Vecchia C. Trends in oesophageal cancer incidence and mortality in Europe. Int J Cancer 2008; 122: 1118-112.

2. Brown LM, Hoover R, Silverman D, Baris D, Hayes R, Swanson GM, Schoenberg J, Greenberg R, Liff J, Schwartz A, Dosemeci M, Pottern L, Fraumeni JF Jr. Excess incidence of squamous cell esophageal cancer among US Black men: role of social class and other risk factors. Am J Epidemiol 2001; 153: 114-122.

3. Lagergren J, Bergstrom R, Lingren A, Nyren O. Symptomatic gastroesophageal reflux as a risk factor for esophageal adenocarcinoma. N Engl J Med 1999; 340: 825-831.

4. Badwe RA, Shsarma V, Bhansali MS, Dinshaw KA, Patil PK, Dalvi N, Rayabhattanavar SG, Desai PB. The quality of swallowing for patients with operable esophageal carcinoma: a randomized trial comparing surgery with radiotherapy. Cancer 1999; 85: 763-768.

5. Siewert Jr, Fink U. Principles of multi-modality therapy in tumors of the gastrointestinal tract. Chirurg 1992; 63: 242-250.
6. Isono K, Ochiai T, Okuyama K, Onoda S. The treatment of lymph node metastasis from esophageal cancer by extensive lymphadenectomy. Jpn J Surg 1990; 20: 151-157.

7. Law S, Wong KH, Wok KF, Chu KM, Wong J. Predictive factors for postoperative pulmonary complications and mortality after esophagectomy for cancer. Ann Surg 2004; 240: 791-800.

8. Luketich JD, Alveo-Rivera M, Buenaventura PO, Christie NA, Mccaughan JS, Litle VR, Schauer PR, Close JM, Fernando HC. Minimally invasive esophagectomy: outcomes in 222 patients. Ann Surg 2003; 238: 486-494.

9. Yamamoto M, Weber JM, Karl RC, Meredith KL. Minimally invasive surgery for esophageal cancer: review of the literature and institutional experience. Cancer Control 2013; 20: 130-137.

10. Nguyen NT, Follette DM, Wolfe BM, Schneider PD, Roberts P, Goodnight Jr. Comparison of minimally invasive esophagectomy with transthoracic and transhiatal esophagectomy. Arch Surg 2000; 135: 920-925.

11. Edge SB, Byrd DR, Compton CC, Fritz AG, Greene FL, Trotti A. AJCC Cancer Staging Handbook From the AJCC Cancer Staging Manual. $7^{\text {th }}$ ed. Springer New York Dordrecht Heidelberg, London 2010.

12. Noguchi Y, Yoshikawa T, Matsumoto A, Svaninger G, Gelin J. Are cytokines possible mediators of cancer cachexia? Surg Today 1996; 26: 467-475.

13. Gabay C, Kusher I. Acute phase protein and other systemic responses to inflammation. N Eng J Med 1999; 340: 448-454.

14. Ueyama M, Maruyama I, Osame M. Marked increase in plasma interleukin-6 in burn patients. J Lab Clin Med 1992; 120: 693-698.

15. Okamura A, Takeuchi H, Matsuda S, Ogura M, Miyasho T, Nakamura R, Takahashi T, Wada N, Kawakubo H, Saikawa Y, Kitagawa Y Factors affecting cytokine change after esophagectomy for esophageal cancer. Ann Surg Oncol 2015; 22: 3130-3135.

16. Kemik Ö, Sarbay Kemik A, Dulger AC, Hasirci I, Dastan E, Bartin MK. The serum levels of interleukin-6 in colon cancer patients with liver metastasis. Van Med J 2010; 17: 42-45.

17. Yu CW, Juan LI, Wu MH, Shen CJ, Wu JY, Lee CC. Systematic review and metaanalysis of the diagnostic accuracy of procalcitonin, C-reactive protein and white blood cell count for suspected acute appendicitis. Br J Surg 2013; 100: 322-329.

18. Falconer JS, Fearon KC, Ross JA, Elton R, Wigmore SJ, Garden OJ, Carter DC. Acute-phase protein response and survival duration of patients with pancreatic cancer. Cancer 1995; 75: 2077-2082.

19. Crumley AB, Mcmillan DC, Mckerman M, Going JJ, Shearer CJ, Stuart RC. An elevated $C$-reactive protein concentration, prior to surgery, predicts poor cancer specific survival in patients undergoing resection for gastro-oesophageal cancer. Br J Cancer 2006; 94: 1568-1571.

20. Ljunberg B, Grankvist K, Rasmuson T. Serum interleukin-6 in relation to acute-phase reactants and survival in patients with renal cell carcinoma. Eur J Cancer 1997; 33: 1794-1798.

21. Huang HT, Wang F, Shen L, Xia CQ, Lu CX, Zhong CJ. Comparison of thoracolaparoscopic esophagectomy with cervical anastomosis with McKeown esophagectomy for middle esophageal cancer. World J Surg Oncol 2015; 13: 310.

22. Li J, Chen J, Kirsner R. Pathophysiology of acute wound healing. Clin Dermatol 2007; 25: 9-18.

23. Stiernberg J, Redin WR, Warner WS, Carney DH. The role of thrombin and thrombin receptor activating peptide (TRAP-508) in initiation of tissue repair. Thromb Haemost 1993; 70: 158-162.

24. Moradi MM, Carson LF, Weinberg B, Haney AF, Twiggs LB. Serum and ascitic fluid levels of interleukin-1, interleukin-6, and tumour necrosis factor-alpha in patients with ovarian epithelial cancer. Cancer 1993; 72: 2433-2440.

25. Aydin Y, Kaplan I, Bilen Y, Bulut C, Genc F, Tukyilmaz A, Eroglu A. Plasma levels of IL-6 and TNF-alpha in patients with esophageal cancer. Turk J Med Sci 2012; 42: 762-767. 